\title{
A Highly Efficient White Luminescent Zinc (II) Based Metallopolymer by RGB Approach
}

\author{
Barbara Panunzi ${ }^{1}$, Rosita Diana ${ }^{1}$ and Ugo Caruso ${ }^{2, *(1)}$ \\ 1 Department of Agriculture, University of Napoli Federico II, 80055 Portici NA, \\ Italy; barbara.panunzi@unina.it (B.P.); rosita.diana@unina.it (R.D.) \\ 2 Department of Chemical Sciences, University of Napoli Federico II, 80126 Napoli, Italy \\ * Correspondence: ugo.caruso@unina.it; Tel.: +39-081-674366
}

Received: 20 September 2019; Accepted: 16 October 2019; Published: 18 October 2019

check for updates

\begin{abstract}
Three aryl-hydrazone $O, N, O$ tridentate ligands with a different electron-withdrawing substituent were prepared. The introduction of a flexible charged chain in the ligands guaranteed solubility in many organic solvents and in water. The increasing withdrawing aptitude of the substituents red-shifted the emission in the correspondent metallopolymers. The metallated polymers were obtained by grafting ligand-zinc (II) coordination fragments onto commercial poly-(4-vinylpyridine). Metallopolymers thin films exhibited red, green and blue emission colors defined by Commission Internationale d'Eclairage (CIE) coordinates and medium to excellent photoluminescence (PL) quantum yields (PLQYs) comparable with other highly-performing active materials for Light-Emitting Diodes (LEDs). By grafting a suitable mix of the three different coordination pendants, an efficient single-component white emissive metallopolymer with CIE $(0.30$, 0.31 ) was prepared. Thanks to the charged moiety, the polymers resulted miscible with an ionic liquid. The addition produced homogeneous polymeric layers with unaltered PL performances, potentially employable in Light-emitting Electrochemical Cells (LECs).
\end{abstract}

Keywords: RGB; Zinc metallopolymer; PLQYs; LECs; WPLEDs

\section{Introduction}

A light-emitting diode (LED) is a semiconductor light source emitting light undercurrent flow. The color of the light is determined by the band gap of the semiconductor. In particular, white light emission has attracted increasing attention, due to the potential for application in lighting devices and displays. The most common way to realize white-light-emitting devices is based on the three-color-mixing method. Red, green and blue (RGB) light-mixing is obtained by a suitable mix of fluorophores. RGB devices are obtained by a multilayer system with sequential deposition of red, green, and blue emissive species, mixed in a physical blend. In the white organic light-emitting devices (WOLEDs) photoluminescent (PL) organic $\pi$-conjugated systems play the leading role. On the other hand, the use of transition metal complexes as emitters in Light-Emitting Diodes (LEDs) technology is well known [1-3]. Due to their excellent PL properties and vivid colors, the rare earths ions have been the first choice for LEDs and white LEDs (WLEDs) [4-6].

More recently, WPLEDs (white polymer LEDs) based on photoactive polymeric layers have joined, and sometimes take place, of the small-molecular based LEDs [7]. In this approach, a polymer blend usually provides the required tuning of white color. Great efforts have been made to realize a simpler and less expensive manufacturing process [8,9]. To achieve these targets, many research groups have concentrated on polymeric active layers of covalently bonded macro-architecture. Dye-doped blends are often employed in WPLEDs production. However, the unique synthetic versatility and processability and the color tuning of the polymers are irreplaceable. To date, 
the challenge to obtain easy and cost-effective solid-state active materials for WPLEDs is geared to the design of new intrinsically PL active macromolecules [10-15], both organic and metallo-based. Polymers containing transition metal complexes (metallopolymers) represent a relevant varied class of materials. Electron rich ligands coordinated to metal centers can enhance optical and electronic properties [16-25]. Rare earths containing metallopolymers have received significant interest [26,27] for the noteworthy PL performance, but the toxicity and high process and disposal costs represent a limit on the production of LED devices.

In previous contributions, we explored the role of the metal in tunable highly emissive complexes and in the related metallopolymers, outside of the rare earths group [26,27]. The embedding of the coordination fluorogenic cores into polymeric chains can transfer the emission properties of the micro-environment to a macro-system, with the advantage to match the desired PL performance with the processability of the polymers. Group 12 metal ions, with $\mathrm{d}^{10}$ cations, keep a special place, due to the versatility in the structural built and the tunability of PL properties [28]. In addition, zinc ion as a biocompatible low-cost metal is one of the most viable alternatives to rare earths. Due to its closed-shell pattern, zinc ion can preserve or enhance PL performances of the chelating ligands, and this causes a growing interest for industrial applications [29-33]. Processable, stable and cheap PL metallopolymers can be obtained by assembly organic moieties and zinc cations.

Here we report on the synthesis of three acyl-hydrazone ligands. The compounds bear fluoro, cyano and nitro substituents, and a flexible charged chain guaranteeing solubility in many organic solvents and in water. The hydrazones $\mathrm{L}_{\mathrm{B}}, \mathrm{L}_{\mathrm{G}}$ and $\mathrm{L}_{\mathrm{R}}$ (Scheme 1 ) act as $O, N, O$ ligands toward zinc ion. An easy synthetic route was employed by grafting the coordination moieties to a preformed poly(4-vinylpyridine) (PVPy) to obtain the polymers $\mathrm{P}_{\mathrm{B}}, \mathrm{P}_{\mathrm{G}}$ and $\mathrm{P}_{\mathrm{R}}$. By increasing the withdrawing strength of the substituent in the ligand, PL color tuning has been achieved. The solid polymers exhibit respectively blue, green and red luminescence with medium to excellent ( $82 \%$ for the green-emissive polymer) PLQYs. By modulating the contents of various emissive pendants into a single polymer chain, an efficient single-component white emissive material $\left(\mathrm{P}_{\mathrm{W}}\right)$ with CIE coordinates $(0.30,0.31)$ was obtained.

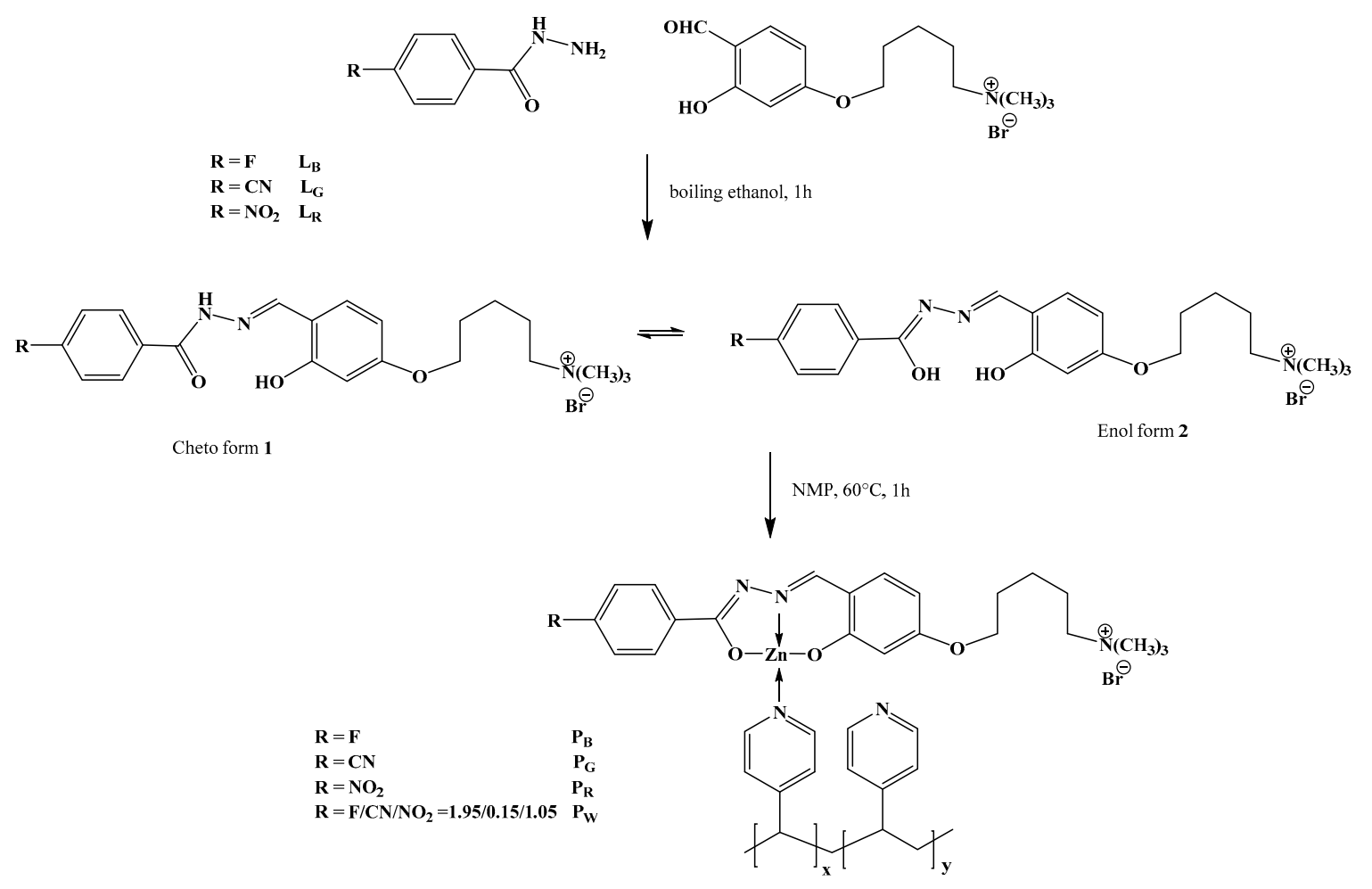

Scheme 1. Synthetic route to ligands $L_{R}, L_{G}$ and $L_{B}$ and metallopolymers $P_{R}, P_{G}, P_{B}$ and $P_{W}$. 
Unlike similar grafted systems $[34,35]$ the charged metallopolymers resulted emissive both in the solid state and in concentered solutions. Moreover, PL performances resulted implemented in color purity and in PLQYs. This feature increases their potential for use in traditional LEDs and even in soft-based light-emitting devices, such as light-emitting electrochemical cells (LECs). LECs are low-cost, easy fabrication lightening devices [16,36-38] based on a luminescent polymer mixed with mobile ionic species or intrinsically ionic transition-metal complexes. The introduction of the flexible chain ending with an ionic group [39-41] in the ligands made the metallated polymers compatible with an ionic medium. Films of the polymers mixed with the ionic liquid 1-butyl-3-methylimidazolium hexafluorophosphate $\left(\mathrm{BMIM} \mathrm{PF}_{6}\right)$ were obtained, and the basic optical and electronic properties examined.

\section{Materials and Methods}

\subsection{Materials}

All starting products and solvents were commercially available. 5-(4-formyl-3-hydroxyphenoxy)-N,N,N-trimethylpentan-1-aminium bromide was prepared accordingly with a known procedure $[42,43] \mathrm{BMIM}^{-\mathrm{PF}_{6}}$ and PVPy $\left(\mathrm{Mw}=60,000\right.$ and $\left.\mathrm{T}_{\mathrm{g}}=137^{\circ} \mathrm{C}\right)$ were Sigma-Aldrich products (chemicals, St. Louis, MO, USA). Optical observations were performed by a Zeiss Axioscop polarizing microscope with an FP90 Mettler heating stage (thermogravimetric analysis, PerkinElmer, Inc., Waltham, MA, USA). By using a DSC scanning calorimeter Perkin Elmer Pyris 1 (DSC scanning calorimeter, PerkinElmer, Inc., Waltham, MA, USA) at a scanning rate of $10{ }^{\circ} \mathrm{C} / \mathrm{min}$, under nitrogen flow, phase transition temperatures and enthalpies were measured. Thermogravimetric analysis was performed by a Perkin Elmer TGA 4000 (thermogravimetric analysis, PerkinElmer, Inc., Waltham, MA, USA). The zinc content was measured as $\mathrm{ZnO}$ residue from TGA analysis. Decomposition temperature was evaluated at $5 \%$ weight loss. ${ }^{1} \mathrm{H}$ NMR of the ligands and the polymers were recorded in 1,1,2,2-TCE $\mathrm{d}_{2}$ using a Bruker Spectrometer operating at $400 \mathrm{MHz}$. UV-Visible absorption and fluorescence emission spectra were recorded by Jasco F-530 spectrometer (scan rate 200 nm min-1, JASCO Inc., Mary's Court, Easton, MD 21601, USA) and Jasco FP-750 spectrofluorometer (JASCO Inc., Mary's Court, Easton, MD, USA) respectively.

\subsection{Thin Films for Optical Measurements and PLQYs Setup}

The thin film sample used for PLQYs were prepared by an SCS P6700 spin-coater apparatus. The in-situ reaction of zinc-driven self-assembly afforded thin films of the metallopolymers by spin-coating the NMP reaction mixture onto quartz slides (operating at $600 \mathrm{rpm}$ for $60^{\prime \prime}$ in a first step and at $1400 \mathrm{rpm}$ for $60^{\prime \prime}$ in a second step) and annealing the films at $150^{\circ} \mathrm{C}$ for $10^{\prime}$. The films were washed with isopropyl alcohol twice and dried at $60^{\circ} \mathrm{C}$ for $20^{\prime}$.

The samples with BMIM-PF ${ }_{6}$ were obtained from a mixture at $10 \% \mathrm{wt}$. of the ionic liquid and the polymer, by spin-coating at $600 \mathrm{rpm}$ for $60^{\prime \prime}$ in a first step and at $1400 \mathrm{rpm}$ for $60^{\prime \prime}$ in a second step on glass substrates. After annealing at $150^{\circ} \mathrm{C}$ for $10^{\prime}$ the films were dried at $60^{\circ} \mathrm{C}$ for $20^{\prime}$ in a vacuum.

PLQY of a molecule or material is defined as the ratio of photons absorbed to photons emitted through fluorescence. Photoluminescence quantum efficiency values of thin films of the polymers were recorded on quartz substrates by a Fluorolog 3 (spectrofluorometer, Horiba Jobin Instruments, Kyoto, Japan). Due to the high refractive index of the films, which results in substantial waveguiding of the luminescence, the spectrofluorometer was equipped with an integrating sphere with an optical fibre connection. This overcomes the angular dependence of the emission from film. A measurement is done of the fluorescence emission $\left(E_{\mathrm{c}}\right)$ and the scatter $\left(L_{\mathrm{c}}\right)$ of the sample and the emission and scatter of a blank ( $L_{\mathrm{a}}$ and $\left.E_{\mathrm{a}}\right)$. From the two spectral measurements (sample and blank), the PLQY can be calculated from the Equation:

$$
\Phi=E_{\mathrm{c}}-(1-A) E_{\mathrm{b}} / L_{\mathrm{a}} \cdot A=E_{\mathrm{c}}-E_{\mathrm{a}} / L_{\mathrm{a}}-L_{\mathrm{c}}
$$


where $E_{\mathrm{b}}$ is the integrated luminescence from the sample caused by indirect luminescence from the sphere and $A$ is the absorbance of the sample at the excitation wavelength.

\subsection{Synthesis of Ligands $L_{R}, L_{G}$ and $L_{B}$}

The ligands were synthesized by the same general procedure. As an example, the synthesis of $\mathrm{L}_{\mathrm{B}}$ is described. To $0.345 \mathrm{~g}(1.00 \mathrm{mmol})$ of 5-(4-formyl-3-hydroxyphenoxy)- $N, N, N$-trimethylpentan-1-aminium bromide dissolved in $15 \mathrm{~mL}$ of ethanol $0.146 \mathrm{~g}(0.95 \mathrm{mmol})$ of 4 -fluoro-benzohydrazide were added. The reaction was kept under stirring at reflux for $30 \mathrm{~min}$. After this time the solution was cooled in an ice bath the precipitation of a whitish crystalline solid ensuing. The solid was recovered by filtration and crystallized from ethanol. Yield: $70 \% . \mathrm{Mp}=262{ }^{\circ} \mathrm{C}$. Decomposition temperature: $319^{\circ} \mathrm{C} .{ }^{1} \mathrm{H}$ NMR $\left(400 \mathrm{MHz}, 1,1,2,2-\mathrm{TCE} \mathrm{d}_{2}\right.$, $\left.25^{\circ} \mathrm{C}\right): \delta=1.13(\mathrm{~m}, 2 \mathrm{H}), 1.90(\mathrm{~m}, 2 \mathrm{H}), 2.22(\mathrm{~m}, 2 \mathrm{H}), 3.42(\mathrm{~s}, 9 \mathrm{H}), 3.79(\mathrm{~m}, 2 \mathrm{H}), 4.09(\mathrm{t}, 2 \mathrm{H}), 6.50(\mathrm{~m}$, $2 \mathrm{H}), 7.27(\mathrm{~m}, 3 \mathrm{H}), 8.30(\mathrm{dd}, 2 \mathrm{H}), 9.00(\mathrm{~s}, 1 \mathrm{H}), 12.02(\mathrm{~s}, 1 \mathrm{H}), 12.14(\mathrm{~s}, 1 \mathrm{H}) \mathrm{ppm}$. Elemental analysis calculated (\%) for $\mathrm{C}_{22} \mathrm{H}_{29} \mathrm{~N}_{3} \mathrm{O}_{3} \mathrm{FBr}$ : C, 54.78; $\mathrm{H}, 6.06 ; \mathrm{N}, 8.71$; found: $\mathrm{C}, 54.93 ; \mathrm{H}, 6.67 ; \mathrm{N}, 8.70$.

$\mathrm{L}_{\mathrm{G}}$ : Yield $77 \%, M p=290{ }^{\circ} \mathrm{C}$. Decomposition temperature: $302{ }^{\circ} \mathrm{C} .{ }^{1} \mathrm{H}$ NMR $(400 \mathrm{MHz}, 1,1,2,2-\mathrm{TCE}$ $\left.\mathrm{d}_{2}, 25^{\circ} \mathrm{C}\right): \delta=1.19(\mathrm{~m}, 2 \mathrm{H}), 2.00(\mathrm{~m}, 2 \mathrm{H}), 2.22(\mathrm{~m}, 2 \mathrm{H}), 3.44(\mathrm{~s}, 9 \mathrm{H}), 3.80(\mathrm{~m}, 2 \mathrm{H}), 4.08(\mathrm{t}, 2 \mathrm{H})$, $6.47(\mathrm{~s}, 1 \mathrm{H}), 6.51(\mathrm{~d}, 1 \mathrm{H}), 7.40(\mathrm{~d}, 3 \mathrm{H}), 8.22(\mathrm{~m}, 2 \mathrm{H}), 8.86(\mathrm{~s}, 1 \mathrm{H}), 11.87(\mathrm{~s}, 1 \mathrm{H}), 12.00(\mathrm{~s}, 1 \mathrm{H}) \mathrm{ppm}$. Elemental analysis calculated (\%) for $\mathrm{C}_{23} \mathrm{H}_{29} \mathrm{~N}_{4} \mathrm{O}_{3} \mathrm{Br}$ : C, 56.45; $\mathrm{H}, 5.97$; N, 11.45; found: $\mathrm{C}, 56.43$; $\mathrm{H}, 6.00 ; \mathrm{N}, 11.33$.

$\mathrm{L}_{\mathrm{R}}$ : Yield $80 \%, \mathrm{Mp}=263{ }^{\circ} \mathrm{C}$. Decomposition temperature: $300{ }^{\circ} \mathrm{C} .{ }^{1} \mathrm{H}$ NMR $(400 \mathrm{MHz}, 1,1,2,2-\mathrm{TCE}$ $\left.\mathrm{d}_{2}, 25^{\circ} \mathrm{C}\right): \delta=1.13(\mathrm{~m}, 2 \mathrm{H}), 1.90(\mathrm{~m}, 2 \mathrm{H}), 2.22(\mathrm{~m}, 2 \mathrm{H}), 3.42(\mathrm{~s}, 9 \mathrm{H}), 3.79(\mathrm{~m}, 2 \mathrm{H}), 4.09(\mathrm{t}, 2 \mathrm{H}) 6.45(\mathrm{~s}$, $1 \mathrm{H}), 6.49(\mathrm{~m}, 1 \mathrm{H}), 7.43(\mathrm{~d}, 1 \mathrm{H}), 8.23(\mathrm{~d}, 2 \mathrm{H}), 8.33(\mathrm{~m}, 2 \mathrm{H}), 8.65(\mathrm{~s}, 1 \mathrm{H}), 11.79(\mathrm{~s}, 1 \mathrm{H}), 12.02(\mathrm{~s}, 1 \mathrm{H})$ ppm. Elemental analysis calculated (\%) for $\mathrm{C}_{22} \mathrm{H}_{29} \mathrm{~N}_{4} \mathrm{O}_{5} \mathrm{Br}$ : C, 51.87; $\mathrm{H}, 5.74 ; \mathrm{N}, 11.00$; found: $\mathrm{C}, 51.43$; $\mathrm{H}, 5.88 ; \mathrm{N}, 11.03$.

\subsection{Synthesis of Metallopolymers $P_{R}, P_{G}, P_{B}$ and $P_{W}$}

The polymers were synthesized by the same general procedure. As an example, the synthesis of $\mathrm{P}_{\mathrm{B}}$ is described. An amount of $0.900 \mathrm{~g}(7.43 \mathrm{mmol})$ dried poly-(4-vinylpyridine) was dissolved in $20 \mathrm{~mL}$ of NMP. Ligand $L_{B}(0.100 \mathrm{~g}, 0.207 \mathrm{mmol})$ was added to the solution under stirring. When all the ligand was dissolved, zinc acetate dihydrate $(0.038 \mathrm{~g}, 0.207 \mathrm{mmol})$ was added. After $1 \mathrm{~h}$ at $60^{\circ} \mathrm{C}$, the solution was poured in $150 \mathrm{~mL}$ of methanol. The precipitated polymer was recovered by filtration and purified by dissolution in NMP and reprecipitation in methanol. Yield: $80 \%$. Alternatively, the same solution was employed to produce in situ thin films.

\subsection{Conductivity Measurements}

In order to determine the electrical conductivity of the films in dark conditions, two silver stripes $(300 \mathrm{~nm})$ were thermally evaporated on the top of the investigated films deposited on glass substrates. The conductivity was calculated by using the Ohm law:

$$
\sigma=\frac{I \cdot s}{V \cdot w \cdot d^{\prime}}
$$

where $I$ is the current, $V$ the voltage, $s$ the distance between two metal stripes, $w$ the length of the stripe and $d$ the thickness of the film. $I$ and $V$ were measured by HP 4140B pA meter/DC voltage source in dark condition.

\section{Results and Discussion}

\subsection{Ligands $L_{R}, L_{G}$ and $L_{B}$}

Multidentate $O, N$ containing ligands as aryl-hydrazones are known for the ability to form stable transition metal complexes with optical and electro-optical properties. The appropriate choice of 
functional substituents on the ligands and of the metal cation are the factors involved in the tuning of PL performance achievable in the derived coordination complexes $[26,44]$. The ligands $L_{R}, L_{G}$ and $L_{B}$ (in Scheme 1) were obtained by condensation reaction between a 4-substituted-benzohydrazide and 5-(4-formyl-3-hydroxyphenoxy)-N,N,N-trimethylpentan-1-aminium bromide [45]. The compounds undergo keto-enol tautomeric interconversion, where keto-amino tautomer 1 is a more stable form than tautomer 2. In a basic solution, the deprotonated enolate 2 tautomer acts as bi-negative $\mathrm{O}, \mathrm{N}, \mathrm{O}$-tridentate ligands.

The identification and evaluation of the purity degree were performed by elemental analysis and ${ }^{1} \mathrm{H}-\mathrm{NMR}$ spectroscopy. Optical observation and differential scanning calorimetry (DSC) was employed to observe crystalline textures and evaluate melting points. Due to the charged chain, the compounds melt after $250{ }^{\circ} \mathrm{C}$ with decomposition temperature above $300^{\circ} \mathrm{C}$ (see Table 1 ).

Table 1. Thermal data of ligands and polymers.

\begin{tabular}{|c|c|c|c|c|c|}
\hline Compound & $M p\left({ }^{\circ} \mathrm{C}\right){ }^{(\mathrm{a})}$ & $T_{\mathrm{g}}\left({ }^{\circ} \mathrm{C}\right)^{(\mathrm{b})}$ & $T_{\mathrm{d}}\left({ }^{\circ} \mathrm{C}\right)^{(\mathrm{c})}$ & $\% \mathrm{ZnO}_{\mathrm{t}}(\mathrm{d})$ & $\% \mathrm{ZnO}_{\text {ex }}{ }^{(\mathrm{e})}$ \\
\hline $\mathrm{L}_{\mathrm{B}}$ & 262 & - & 310 & - & - \\
\hline $\mathrm{L}_{\mathrm{G}}$ & 290 & - & 302 & - & - \\
\hline $\mathrm{L}_{\mathrm{R}}$ & 263 & - & 300 & - & - \\
\hline $\mathrm{P}_{\mathrm{B}}$ & - & 172 & 340 & 1.66 & 1.70 \\
\hline$P_{G}$ & - & 188 & 335 & 1.64 & 1.66 \\
\hline $\mathrm{P}_{\mathrm{R}}$ & - & 171 & 330 & 1.57 & 1.59 \\
\hline $\mathrm{P}_{\mathrm{W}}$ & - & 168 & 330 & 1.63 & 1.60 \\
\hline
\end{tabular}

(a) Melting point. ${ }^{(b)}$ Glass transition temperature. ${ }^{(c)}$ Decomposition temperature. ${ }^{(d)}$ Zinc content calculated as $\mathrm{ZnO}$. ${ }^{(e)} \mathrm{Zn}$ content experimentally determined as $\mathrm{ZnO}$.

The ligands show low green-yellow emission in diluted ethanol solution (PLQYs 1.5\% for $\mathrm{L}_{\mathrm{B}}, 0.80 \%$ for $\mathrm{L}_{\mathrm{R}}$ and $2.1 \%$ for $\mathrm{L}_{\mathrm{G}}$ ) and no relevant solvatochromism depending on the solvent polarity. Contrarily to similar not charged hydrazones [45,46], PLQYs measured on crystalline powder are appreciable for the fluoro and cyano derivatives (3.0\% and $5.1 \%$ respectively), scarce for the nitro compound $(0.7 \%)$. The emission maxima in the solid state, recorded in the green-yellow region, resulted slightly red-shifted, depending of the withdrawing strength of the substituent. As expected [45], ligands produce strong emission and an effective color tuning effect only after freezing in the planar rigid conformation, due to zinc coordination. Absorbance and emission maxima recorded in ethanol and on the neat crystalline solids are reported in Table 2.

Table 2. Optical data of ligands and polymers.

\begin{tabular}{cccccc}
\hline Compound & $\lambda_{\text {abs.sol }}(\mathbf{n m})^{(\mathbf{a})}$ & $\lambda_{\text {em.sol }}(\mathbf{n m})^{(\mathbf{b})}$ & $\lambda_{\text {abs.film }}(\mathbf{n m})^{(\mathbf{c})}$ & $\lambda_{\text {em.film }}$ (nm) $^{(\mathbf{d})}$ & PLQY\% $^{\text {(e) }}$ \\
\hline $\mathrm{L}_{\mathrm{B}}$ & 329 & $411(490)$ & 330 & 501 & $3.0 \pm 0.2$ \\
\hline $\mathrm{L}_{\mathrm{G}}$ & 339 & 512 & 340 & 521 & $5.1 \pm 0.2$ \\
\hline $\mathrm{L}_{\mathrm{R}}$ & 346 & 479 & 380 & 570 & $0.7 \pm 0.1$ \\
\hline $\mathrm{P}_{\mathrm{B}}$ & 344 & 492 & $(316) 386$ & 474 & $71 \pm 2$ \\
\hline $\mathrm{P}_{\mathrm{G}}$ & 343 & 516 & $(318) 430$ & 526 & $82 \pm 2$ \\
\hline $\mathrm{P}_{\mathrm{R}}$ & 435 & 502 & $(329) 435$ & 620 & $25 \pm 2$ \\
\hline $\mathrm{P}_{\mathrm{W}}$ & $354($ broad) & $400-600$ (weak) & $251(315,387)$ & $350-700$ & $57 \pm 2$
\end{tabular}

(a) Wavelength of UV-Visible absorbance maxima in ethanol solution (ligands) and N-Methyl-2-pyrrolidone (NMP) solution (polymers). ${ }^{(b)}$ Wavelength of emission maxima in ethanol solution (ligands) and NMP solution (polymers). (c) Wavelength of UV-Visible absorbance maxima on a thin film obtained from the neat samples. ${ }^{\text {(d) Wavelength of }}$ emission maxima on a thin film obtained from the neat samples. ${ }^{(e)}$ PL quantum yield measured on thin films. 


\subsection{Polymers $P_{R}, P_{G}, P_{B}$ and $P_{W}$}

We previously proposed a coordination approach based on the use of $O, N, O$ ligands for transition metals as copper, nickel, palladium, cadmium and zinc $[25,47-49]$ leading to highly stable complexes. Due to its closed-shell pattern and to the biocompatibility, zinc ion is a good candidate for devices production. This metal resulted able to enhance PL performances of the chelating ligands, determining the color tuning in the final materials. According to previous results [20], when the bi-negative ligand coordinate to zinc (II) ion, the coordination sphere can be completed by neutral pyridine molecules. The ability of pyridine to complete the coordination core of the complex was exploited for preparing metallopolymers by chemical grafting ligand-metal moieties onto commercially available poly (4-vinylpyridine) (PVPy, $\mathrm{Mw}=60,000$ and $T_{\mathrm{g}}=137^{\circ} \mathrm{C}$ ) as summarized in Scheme 1 . This approach was demonstrated to produce metallated polymers with nominal concentrations, where the molecular weights of the metallopolymers depend on the grafting percentage and can be adjusted by varying $\mathrm{Mw}$ of the preformed chain.

Respect to the common practice of physical doping of a fluorophore in a non-emissive polymeric host matrix, this synthetic strategy represents an easy and cost-effective alternative. The practice experimented before with rare earths metals [44] in our case, adds the advantage of a biocompatible metal and excellent PLQYs at a low grafting percentage. Thanks to the chemical bond between metal centers and polymer chain, undesirable local structuring or phase separation can be avoided. Moreover, a single material is easier to process in the device fabrication.

According to previous studies [35], the best match between good PL performance and processability were obtained in $10 \mathrm{wt} . \%$ samples, composition expressed as ligand/(ligand+PVPy)\%. This result comes from a particular situation. DFT calculation was previously performed on similar crystalline model complexes. HOMO was found mainly on the molecular plane of the ligand and LUMO on the pyridines that completed the coordination sphere [35]. The environment of the fluorophore units in the polymers resembles a pyridine concentered solution. In the $10 \%$ grafted polymers intermolecular interactions among fluorophores are reduced, due to the large number of surrounding pyridine units (where LUMO is located) of the polymeric chain and to the electrostatic repulsions between the cationic chains [50-52]. This additional factor justifies PLQYs increased by a factor 10 with respect to strictly similar emissive metallopolymers, without charged chain [35]. Samples with percentage quite higher $10 \%$ undergo aggregation caused quenching effect (ACQ) [53-55] related to rapid nonradiative decays of the excimers of neighboring fluorophores. Samples with percentages quite lower than $10 \%$ show poor emission, due to the scarce number of ligand moieties (where HOMO is located).

The metallopolymers are soluble in common organic solvents and exhibit good viscosity for film deposition (from N-methyl pyrrolidone, NMP, or ortho-dichlorobenzene, o-DCB, concentered solutions). Polymer solutions resulted stable for six months at least. No evidence of crystallinity was detected both in optical observations and in the DSC pattern. Respect to the free PVPy, the glass transition temperature increases from 31 to $51^{\circ} \mathrm{C}$ as a result of the grafting process (see Table 1). The TGA curves recorded from 50 to $600^{\circ} \mathrm{C}$ on the solid samples show no weight loss below $340^{\circ} \mathrm{C}$ (Table 1). Zinc content determined as $\mathrm{ZnO}$ from the residue at $600^{\circ} \mathrm{C}$ (see Experimental Section) is in good agreement with the calculated residue. The ${ }^{1} \mathrm{H}-\mathrm{NMR}$ spectra generally appear consistent with the expected structure, but the intensity of the NMR signals of the metal-ligand fragments resulted very low with respect to PVPy backbone signals, and not clearly detectable. This behavior is observable in Figure 1, where the ${ }^{1} \mathrm{H}$-NMR spectrum of $\mathrm{L}_{\mathrm{B}}$ and the correspondent metallopolymer $\mathrm{P}_{\mathrm{B}}$ are compared. 


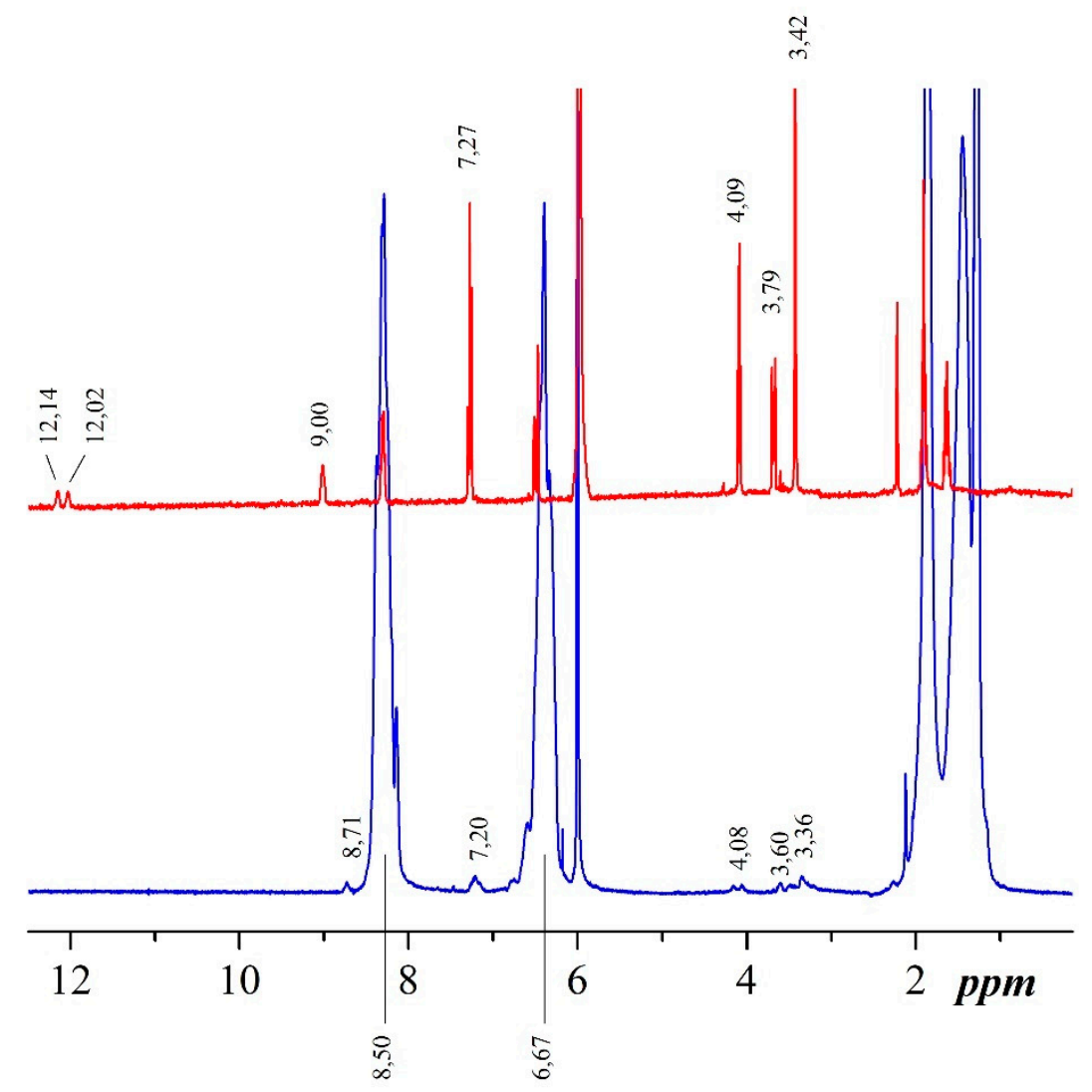

Figure 1. ${ }^{1} \mathrm{H}-\mathrm{NMR}$ spectrum of $\mathrm{L}_{\mathrm{B}}$ (red curve) and the correspondent metallopolymer $\mathrm{P}_{\mathrm{B}}$ (blue curve). The diagnostic resonances are evidenced.

The spectral pattern of the grafted polymer (blue curve) is consistent with the coordinative bond between the metal-ligand fragment and the PVPy chain. Some of the signals pertaining to the coordination core can be recognized. The resonance ascribable to the tridentate ligand $\mathrm{CH}=\mathrm{N}$ proton at $8.71 \mathrm{ppm}$ is observed at $9.00 \mathrm{ppm}$ in the free ligand (red curve). Most aromatic resonances are overlapped by the two intense and broad signals centered at 8.50 and $6.67 \mathrm{ppm}$, due to the polymeric backbone. Only the signal at $7.20 \mathrm{ppm}$ (recorded at $7.27 \mathrm{ppm}$ in the spectrum of the ligand) can be clearly detected. As expected, the signals, due to the $\mathrm{NH}$ and $\mathrm{OH}$ group (respectively at 12.14 and $12.02 \mathrm{ppm}$ in the cheto form of the ligand) are absent in the polymer spectrum. The signals at 4.08 , 3.60 and $3.36 \mathrm{ppm}$ in the blue curve is related to the ones at 4.09, 3.79 and $3.42 \mathrm{ppm}$ (for the ligand), due to $\mathrm{OCH}_{2}, \mathrm{NCH}_{2}$ and $\mathrm{N}\left(\mathrm{CH}_{3}\right)_{3}$ groups. Finally, the resonance of a $\mathrm{CH}_{2}$ group in the alkoxy chain of $\mathbf{L}_{\mathbf{B}}$ is clearly visible at 2.22 in the spectrum of $\mathrm{P}_{\mathbf{B}}$, while the rest is overlapped to the polymeric chain signals, from about $1.05 \mathrm{ppm}$ and $2.10 \mathrm{ppm}$.

Polymeric thin films were obtained by dissolving the polymer in NMP and spin-coating on quartz slides. A more facile one-step in-situ route was also employed. The films produced according to the two methods showed the same properties. As described in the Experimental Section, the reaction mixture of ligand, zinc salt and PVPy can be directly spin-coated on quartz slides. After curing, washing and drying processes, the glassy thin films were employed to explore PL performances in the solid state. The one-step approach not needing a catalyst or initiator is a desirable technique used to depose the emissive layers onto the electrodes in LEDs and other light-emitting devices [56]. According to what observed for analogous systems [35], one or maybe two pyridine molecules could be involved as $\mathrm{N}$ donor ligands in penta- or hexacoordinated arrangements. For this reason, no permanent crosslinking is produced in the solid samples. This justifies the high tenacity and adhesion to the quartz substrate and the solubility, at the same time. 
The polymeric films of $\mathrm{P}_{\mathrm{B}}, \mathrm{P}_{\mathrm{G}}$ and $\mathrm{P}_{\mathrm{R}}$ emit respectively in the blue, green and red region of the visible spectrum, as perceptible even to the naked eye (see Figure 2, inset). Commission Internationale de l'Eclairage (CIE) coordinates are $(0.17,0.24),(0.32,0.56)$ and $(0.54,0.44)$ respectively. From medium to large Stokes Shifts (from $88 \mathrm{~nm}$ to $185 \mathrm{~nm}$ ) were recorded, from absorbance (in the visible region) to emission maximum wavelength. This relevant parameter affects the intensity and color purity of the PL emission in LEDs.

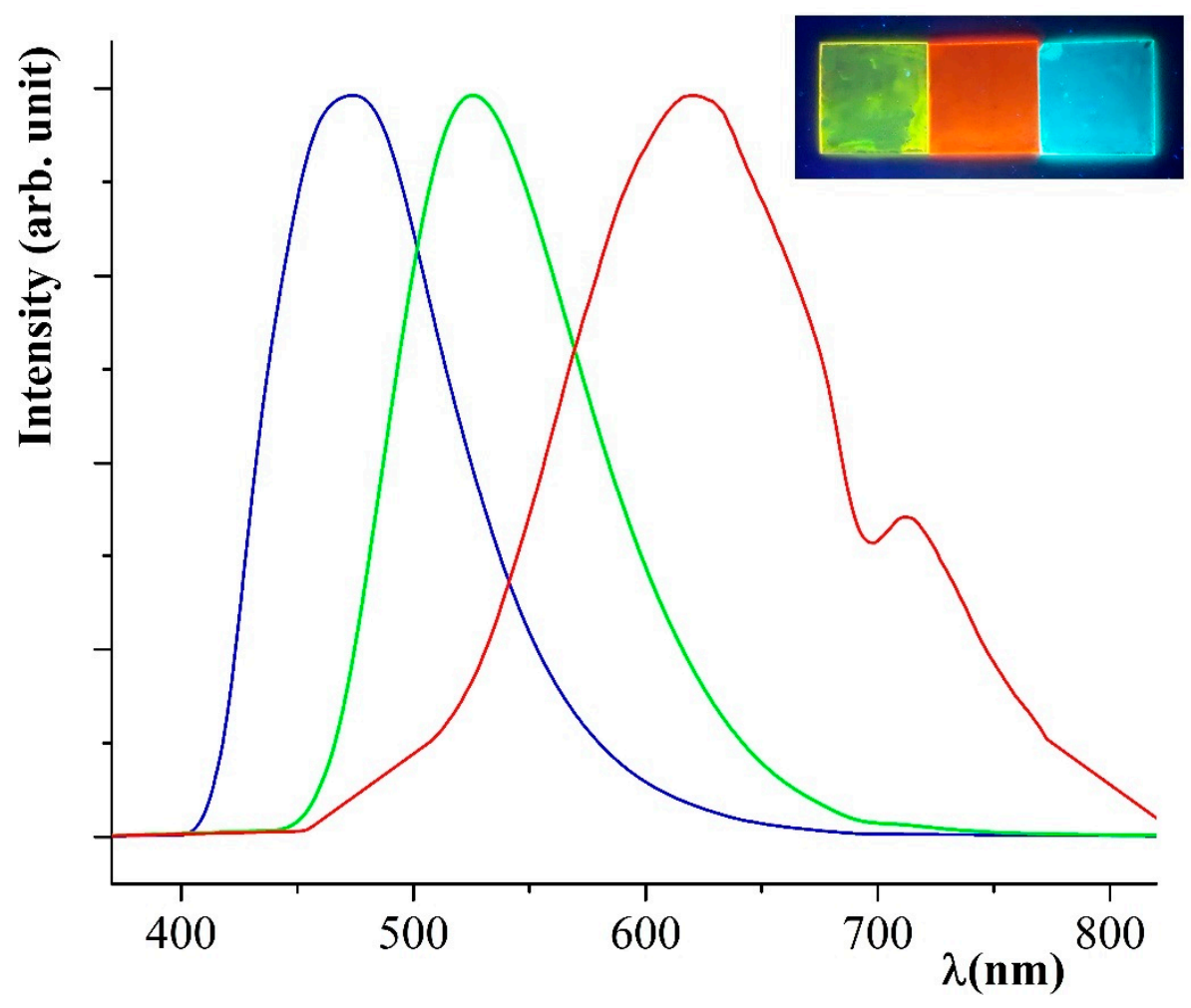

Figure 2. Normalized emission curves recorded on thin film (blue curve) samples of $P_{B}$ (blue curve), $\mathrm{P}_{\mathrm{G}}$ (green curve) and $\mathrm{P}_{\mathrm{R}}$ (red curve). In the inset: The same spin-coated thin films (respectively $\mathrm{P}_{\mathrm{G}}$, $P_{R}$ and $P_{B}$ from left to right) photographed under the UV lamp at $365 \mathrm{~nm}$.

PLQYs measured on the blue and on the green luminescent thin films of $\mathrm{P}_{\mathrm{B}}$ and $\mathrm{P}_{\mathrm{G}}$ are above $70 \%$ (Table 2). As far as we know, $82 \%$ measured for $P_{G}$ is unprecedented for a PL metallopolymer. On this base, both polymers can be effective emitters for classical blue and green LEDs. On the other hand, PLQY of $\mathrm{P}_{\mathrm{R}}(25 \%)$ is even remarkable because red fluorophores usually provide lower-emission energy, according to the "energy gap low" [57,58]. In all cases, emission resulted implemented both in color purity and in PLQYs respect to the PL metallopolymers we studied in the past $[17,25,35,57]$.

Due to the nature of the charged ligand, the metallopolymers show emission in concentered solutions, while similar not charged systems had worst PL performance [35]. Appreciable PLQYs measured in NMP diluted solutions are from $5.3 \%$ (for $\left.\mathrm{P}_{\mathrm{G}}\right)$ to $4.5 \%\left(\mathrm{P}_{\mathrm{B}}\right)$ and $1.5 \%\left(\mathrm{P}_{\mathrm{R}}\right)$. In Table 2 are reported the emission maxima of the same solutions. In a diluted system, the RGB tuning effect is lost, and the emissions are recorded in the lime-yellow region for all samples.

Starting from the information collected on the single metallopolymers, we prepared an efficient single-component white emissive material $\left(\mathrm{P}_{\mathrm{W}}\right)$. Since conventional emissive layers in light-emitting devices are composed of three components, morphological stability problems, due to phase separation can occur. In this regards, a single-component emissive polymer incorporating RGB emissive species into a single polymer chain is an intriguing novel approach [59]. In our case, the easiness of the synthesis and of the film deposition makes it the ideal solution. 
A suitable mix of the three different coordination moieties was realized by modulating the contents of the three emissive pendants. The emission in the solid state of the white polymer was realized in the stoichiometric ratio $\mathrm{B} / \mathrm{G} / \mathrm{R}=1.95 / 0.15 / 1.05$ in moles at $10 \%$ total grafting percentage (expressed as ligand/(ligand+PVPy)\%.). The red emissive component must be carefully dosed because it causes a decrease in the PL efficiency of the whole system. The spin-coated thin film of $\mathrm{P}_{\mathrm{W}}$ under UV lamp at $255 \mathrm{~nm}$ is pictured in Figure 3 (inset). The fluorescence spectra of the same sample irradiated at $255 \mathrm{~nm}$ appear as a single broad band from about 350 to $700 \mathrm{~nm}$. The point in the "RGB triangle" with CIE coordinates of $(0.30,0.31)$, shown in Figure 3 corresponds to the emission of $P_{W}$, slightly shifted in the blue region, but highly efficient. PLQY measured on the polymer is $37 \%$, to the best of our knowledge, this is an excellent value for a single-component white emissive material in the solid state [60-62].

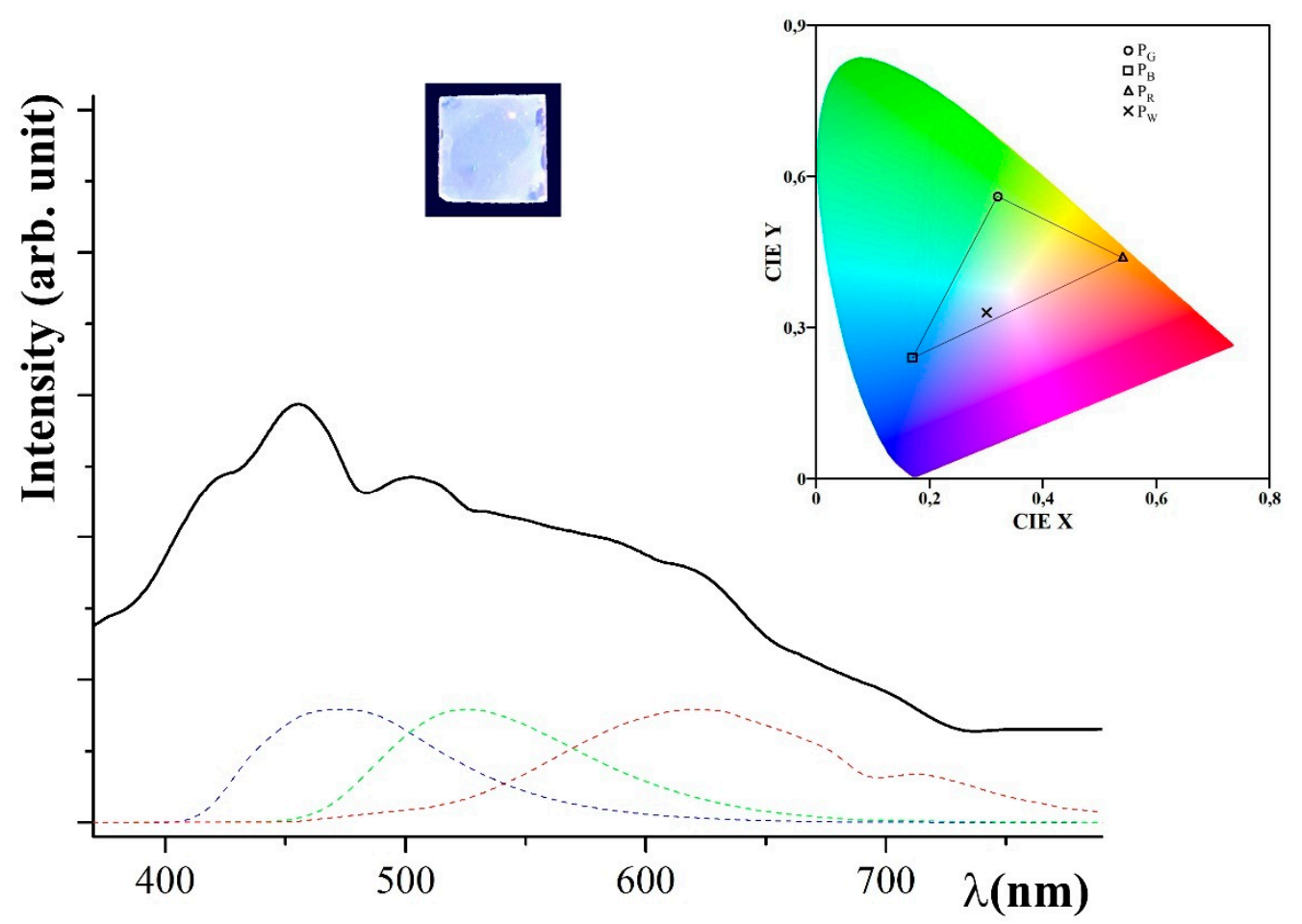

Figure 3. Emission curve recorded on a thin film of $\mathrm{P}_{\mathrm{w}}$ (black curve). Under $\mathrm{P}_{\mathrm{B}}$ (blue curve), $\mathrm{P}_{\mathrm{G}}$ (green curve) and $P_{R}$ (red curve). The same spin-coated thin films photographed under the UV lamp at $255 \mathrm{~nm}$ in the inset. CIE 1931 RGB color space for the polymer samples.

Due to their PL performance, synthetic easiness and processability in the solid state, we demonstrated the potential of the neat polymers for classical LEDs and WPLEDs construction. As potentially active layers of LECs, the first requirement to be met is the compatibility with an ionic medium. This preliminary test was performed by mixing the metallopolymers with the ionic liquid $\mathrm{BMIM}_{\mathrm{PF}}$. Homogeneous thin films of the blends were obtained by spin-coating technique [21,24,63-68]. Interestingly, the addition of $10 \%$ wt. BMIM-PF 6 [65] did not make any significant changes in the processability and PL properties (color and PLQY) of the single red, green and blue emissive polymers, and of the white polymer. On the other hand, as a brief glimpse of feasibility, we measured the electrical conductivity in dark conditions of the films with and without the addition of the ionic liquid. As can be seen in Table 3, the conductivity of the red, green, blue and white blend samples deposed on glass substrates increase of a factor from $10^{2}$ to $10^{4}$ respect to the neat samples. The conductivity of $\mathrm{P}_{\mathrm{W}}$ is higher by a factor 10 respect to the green polymer and 100 respect to the blue and red ones. No wonder though values of the electrical conductivity on optimized LEC devices are typically 100 times greater $[64,69,70]$. The thickness of the films, type and percentage of ionic liquid are relevant parameters that must be optimized. Nevertheless, the collected data can be 
considered an interesting starting point for the employ of our polymers, also in the fabrication of LECs active layers.

Table 3. Electrical conductivity measured on neat polymeric samples and on 1-butyl-3-methylimidazolium hexafluorophosphate $\left(\mathrm{BMIM}^{\left.-\mathrm{PF}_{6}\right)}\right.$ ) blends.

\begin{tabular}{ccc}
\hline Compound & BMIM-PF $_{\mathbf{6}}(\boldsymbol{\%} \mathbf{w t})$. & Conductivity $(\boldsymbol{\mu S} / \mathbf{m})$ \\
\hline $\mathrm{P}_{\mathrm{B}}$ & 0 & $1.9 \cdot 10^{-4}$ \\
$\mathrm{P}_{\mathrm{G}}$ & 0 & $4.4 \cdot 10^{-3}$ \\
$\mathrm{P}_{\mathrm{R}}$ & 0 & $1.5 \cdot 10^{-4}$ \\
$\mathrm{P}_{\mathrm{W}}$ & 0 & $2.3 \cdot 10^{-2}$ \\
$\mathrm{P}_{\mathrm{B}}$ & 10 & $5.7 \cdot 10^{-2}$ \\
$\mathrm{P}_{\mathrm{G}}$ & 10 & $1.3 \cdot 10^{-1}$ \\
$\mathrm{P}_{\mathrm{R}}$ & 10 & $3.4 \cdot 10^{-2}$ \\
$\mathrm{P}_{\mathrm{W}}$ & 10 & 1.5 \\
\hline
\end{tabular}

\section{Conclusions}

Three hydrazone tridentate ligands with a different electron-withdrawing substituent and a flexible charged chain were employed as ligand-zinc (II) coordination fragments, grafted onto commercial PVPy. Blue, green and red solid-state emission with CIE coordinates $(0.17,0.24),(0.32,0.56)$ and $(0.54$, 0.44 ) has been achieved by increasing withdrawing aptitude of the substituent. To the easy synthetic approach, the advantage of a biocompatible metal and good PL performance at low grafting percentage were added. PLQYs measured on in situ spin-coated thin films reach the outstanding $82 \%$ PLQY for $P_{G}$, which shows great potential as an active layer of green LEDs. By grafting an appropriate choice of different coordination pendants, it was obtained an efficient single-component white emissive metallopolymer based on simultaneous RGB emission, CIE coordinates $(0.30,0.31)$. With the noteworthy 37\% PLQY the white-emissive polymer appears very promising as a single-emissive material for WPLEDs.

The insertion of the charged chain proved to be helpful to make the metallopolymers miscible with an ionic liquid. The potential as LECs active layers were tested on polymer/BMIM-PF 6 blends, obtaining homogeneous layers with preserved PL performances. Though the thickness of the films and ionic liquid content must be optimized, the conductivity measured on the blends can be considered a promising starting point for actual employ for LECs layers.

Author Contributions: Conceptualization, U.C. and B.P.; data curation and formal analysis, R.D.; funding acquisition, U.C.; investigation, U.C.; methodology, R.D. and B.P.; project administration, U.C.; resources, U.C.; writing — original draft, U.C. and B.P.; writing—review \& editing, U.C.

Funding: This research was funded by the Italian Ministry of Education, University and Research (MIUR) (Piano Lauree Scientifiche "Scienza dei Materiali" 2016-2018).

Conflicts of Interest: The authors declare no conflict of interest.

\section{References}

1. Frohleiks, J.; Wepfer, S.; Bacher, G.; Nannen, E. Realization of red iridium-based ionic transition metal complex light-emitting electrochemical cells (iTMC-LECs) by interface-induced color shift. Acs Appl. Mater. Inter. 2019, 11, 22612-22620. [CrossRef] [PubMed]

2. Hosseini, A.R.; Koh, C.Y.; Slinker, J.D.; Flores-Torres, S.; Abruña, H.D.; Malliaras, G.G. Addition of a Phosphorescent Dopant in Electroluminescent Devices from Ionic Transition Metal Complexes. Chem. Mater. 2005, 17, 6114-6116. [CrossRef]

3. Carlson, B.; Phelan, G.D.; Jiang, X.; Kaminsky, W.; Jen, A.K.Y.; Dalton, L.R. Organic light emitting devices based upon divalent osmium complexes: Part 1: design, synthesis, and characterization of osmium complexes. In Organic Light-Emitting Materials and Devices VI; International Society for Optics and Photonics: Seattle, WA, USA, 2003; Volume 4800, pp. 93-104. [CrossRef] 
4. Tian, M.; Li, P.; Wang, Z.; Li, Z.; Cheng, J.; Sun, Y.; Wang, C.; Teng, X.; Yang, Z.; Teng, F. Controlling multi luminescent centers via anionic polyhedron substitution to achieve single $\mathrm{Eu}^{2+}$ activated high-color-rendering white light/tunable emissions in single-phased $\mathrm{Ca}_{2}\left(\mathrm{BO}_{3}\right)_{1-\mathrm{x}}\left(\mathrm{PO}_{4}\right) \mathrm{Cl}$ phosphors for ultraviolet converted LEDs. Chem. Eng. J. 2017, 326, 667-679. [CrossRef]

5. Kumar, M.; Dubey, S.; Rajendar, V.; Park, S.-H. Fabrication of ZnO thin films by sol-gel spin coating and their UV and white-light emission properties. J. Electron. Mater. 2017, 46, 6029-6037. [CrossRef]

6. He, Z.; Zhao, W.; Lam, J.W.Y.; Peng, Q.; Ma, H.; Liang, G.; Shuai, Z.; Tang, B.Z. White light emission from a single organic molecule with dual phosphorescence at room temperature. Nat. Commun. 2017, 8, 416. [CrossRef]

7. D'Andrade, B.W.; Holmes, R.J.; Forrest, S.R. Efficient organic electrophosphorescent White-Light-Emitting Device with a Triple Doped Emissive Layer. Adv. Mater. 2004, 16, 624-628. [CrossRef]

8. Gong, X.; Ma, W.; Ostrowski, J.C.; Bazan, G.C.; Moses, D.; Heeger, A.J. White electrophosphorescence from Semiconducting Polymer Blends. Adv. Mater. 2004, 16, 615-619. [CrossRef]

9. Cheng, G.; Li, F.; Duan, Y.; Feng, J.; Liu, S.; Qiu, S.; Lin, D.; Ma, Y.; Lee, S.T. White organic light-emitting devices using a phosphorescent sensitizer. Appl. Phys. Lett. 2003, 82, 4224-4226. [CrossRef]

10. Gill, R.E.; van Hutten, P.F.; Meetsma, A.; Hadziioannou, G. Synthesis and Crystal Structure of a Cyano-Substituted Oligo(p-phenylenevinylene). Chem. Mater. 1996, 8, 1341-1346. [CrossRef]

11. Caruso, U.; Diana, R.; Panunzi, B.; Roviello, A.; Tingoli, M.; Tuzi, A. Facile synthesis of new Pd(II) and Cu(II) based metallomesogens from ligands containing thiophene rings. Inorg. Chem. Commun. 2009, 12, 1135-1138. [CrossRef]

12. Xin, Y.; Shen, W.; Deng, Z.; Zhang, J. Highly Emissive and Color-Tunable Perovskite Cross-linkers for Luminescent Polymer Networks. ACS Appl. Mater. Interfaces 2018, 10, 28971-28978. [CrossRef] [PubMed]

13. Liu, C.; Luo, H.; Shi, G.; Yang, J.; Chi, Z.; Ma, Y. Luminescent network film deposited electrochemically from a carbazole functionalized AIE molecule and its application for OLEDs. J. Mater. Chem. C 2015, 3, 3752-3759. [CrossRef]

14. Li, M.; Tang, S.; Shen, F.; Liu, M.; Xie, W.; Xia, H.; Liu, L.; Tian, L.; Xie, Z.; Lu, P.; et al. Highly luminescent network films from electrochemical deposition of peripheral carbazole functionalized fluorene oligomer and their applications for light-emitting diodes. Chem. Commun. 2006, 32, 3393-3395. [CrossRef] [PubMed]

15. Roviello, A.; Borbone, F.; Carella, A.; Diana, R.; Roviello, G.; Panunzi, B.; Ambrosio, A.; Maddalena, P. High quantum yield photoluminescence of new polyamides containing oligo-PPV amino derivatives and related oligomers. J. Polym. Sci. Part A Polym. Chem. 2009, 47, 2677-2689. [CrossRef]

16. Costa, R.D.; Orti, E.; Bolink, H.J.; Monti, F.; Accorsi, G.; Armaroli, N. Luminescent ionic transition-metal complexes for light-emitting electrochemical cells. Angew. Chem. Int. Ed. 2012, 51, 8178-8211. [CrossRef]

17. Diana, R.; Panunzi, B.; Shikler, R.; Nabha, S.; Caruso, U. Highly efficient dicyano-phenylenevinylene fluorophore as polymer dopant or zinc-driven self-assembling building block. Inorg. Chem. Commun. 2019, 104, 145-149. [CrossRef]

18. Panunzi, B.; Borbone, F.; Capobianco, A.; Concilio, S.; Diana, R.; Peluso, A.; Piotto, S.; Tuzi, A.; Velardo, A.; Caruso, U. Synthesis, spectroscopic properties and DFT calculations of a novel multipolar azo dye and its zinc(II) complex. Inorg. Chem. Commun. 2017, 84, 103-108. [CrossRef]

19. Kwon, S.K.; Lee, Y.K.; Park, T.J.; Uchiike, H.; Kwon, J.H.; Jang, J.; Jin, J.K.; Shin, D.C.; You, H. High-Efficiency White Polymer Light-Emitting Diodes Based on Blended RGB Polymers. Mol. Cryst. Liq. Cryst. 2006, 458, 263-272. [CrossRef]

20. Panunzi, B.; Concilio, S.; Diana, R.; Shikler, R.; Nabha, S.; Piotto, S.; Sessa, L.; Tuzi, A.; Caruso, U. Photophysical Properties of Luminescent Zinc(II)-Pyridinyloxadiazole Complexes and their Glassy Self-Assembly Networks. Eur. J. Inorg. Chem. 2018, 2018, 2709-2716. [CrossRef]

21. Di Marcantonio, M.; Vollkommer, F.; Bacher, G.; Nannen, E. A light-emitting electrochemical cell (LEC) containing a hole-blocking layer of TmPyPB. J. Mater. Chem. C 2018, 6, 9742-9748. [CrossRef]

22. Diana, R.; Caruso, U.; Concilio, S.; Piotto, S.; Tuzi, A.; Panunzi, B. A real-time tripodal colorimetric/fluorescence sensor for multiple target metal ions. Dyes Pigm. 2018, 155, 249-257. [CrossRef]

23. Oliveri, I.P.; Failla, S.; Malandrino, G.; Bella, S.D. New molecular architectures by aggregation of tailored zinc(ii) Schiff-base complexes. New J. Chem. 2011, 35, 2826-2831. [CrossRef] 
24. Nishikitani, Y.; Cho, T.; Uchida, S.; Nishimura, S.; Oyaizu, K.; Nishide, H. Polymer-based white-light-emitting electrochemical cells with very high color-rendering index based on blue-green fluorescent polyfluorenes and red-phosphorescent iridium complexes. ChemPlusChem 2018, 83, 463-469. [CrossRef]

25. Borbone, F.; Caruso, U.; Concilio, S.; Nabha, S.; Piotto, S.; Shikler, R.; Tuzi, A.; Panunzi, B. From cadmium(II)-aroylhydrazone complexes to metallopolymers with enhanced photoluminescence. A structural and DFT study. Inorg. Chim. Acta 2017, 458, 129-137. [CrossRef]

26. Chen, H.; Zhang, W.; Lin, Z.; Ling, Q. White-light hydrotalcite-like compound emission from the incorporation of red-, green-, and blue-emitting metal complexes. Opt. Mater. Express 2012, 3, 105-113. [CrossRef]

27. Zhang, A.; Xu, W.; Chen, R.; Wang, Z.; Yan, Q.; Miao, Y.; Jia, H.; Xu, B.; Wong, W.-Y. Program controlling the emission color of blend polymer phosphors containing Eu(III), Tb(III), Be(II) ions for WLEDs. Opt. Mater. 2019, 89, 250-260. [CrossRef]

28. Farinella, F.; Maini, L.; Mazzeo, P.P.; Fattori, V.; Monti, F.; Braga, D. White luminescence achieved by a multiple thermochromic emission in a hybrid organic-inorganic compound based on 3-picolylamine and copper(i) iodide. Dalton Trans. 2016, 45, 17939-17947. [CrossRef]

29. Lin, R.B.; Liu, S.Y.; Ye, J.W.; Li, X.Y.; Zhang, J.P. Photoluminescent metal-organic frameworks for gas sensing. Adv. Sci. 2016, 3, 1500434. [CrossRef]

30. Cui, Y.; Yue, Y.; Qian, G.; Chen, B. Luminescent functional metal-organic frameworks. Chem. Rev. 2012, 112, 1126-1162. [CrossRef]

31. Falcaro, P.; Ricco, R.; Doherty, C.M.; Liang, K.; Hill, A.J.; Styles, M.J. MOF positioning technology and device fabrication. Chem. Soc. Rev. 2014, 43, 5513-5560. [CrossRef]

32. Mendiratta, S.; Lee, C.H.; Usman, M.; Lu, K.L. Metal-organic frameworks for electronics: emerging second order nonlinear optical and dielectric materials. Sci. Technol. Adv. Mater. 2015, 16, 054204. [CrossRef] [PubMed]

33. Di Serio, M.; Carotenuto, G.; Cucciolito, M.E.; Lega, M.; Ruffo, F.; Tesser, R.; Trifuoggi, M. Shiff base complexes of zinc(II) as catalysts for biodiesel production. J. Mol. Catal. A Chem. 2012, 353, 106-110. [CrossRef]

34. Borbone, F.; Caruso, U.; Concilio, S.; Nabha, S.; Panunzi, B.; Piotto, S.; Shikler, R.; Tuzi, A. Mono-, Di-, and Polymeric Pyridinoylhydrazone ZnII Complexes: Structure and Photoluminescent Properties. Eur. J. Inorg. Chem. 2016, 2016, 818-825. [CrossRef]

35. Borbone, F.; Caruso, U.; Palma, S.D.; Fusco, S.; Nabha, S.; Panunzi, B.; Shikler, R. High solid state photoluminescence quantum yields and effective color tuning in polyvinylpyridine based zinc(II) metallopolymers. Macromol. Chem. Phys. 2015, 216, 1516-1522. [CrossRef]

36. Meier, S.B.; Tordera, D.; Pertegás, A.; Roldán-Carmona, C.; Ortí, E.; Bolink, H.J. Light-emitting electrochemical cells: recent progress and future prospects. Mater. Today 2014, 17, 217-223. [CrossRef]

37. Fresta, E.; Costa, R.D. Beyond traditional light-emitting electrochemical cells-A review of new device designs and emitters. J. Mater. Chem. C 2017, 5, 5643-5675. [CrossRef]

38. Xiong, Y.; Li, L.; Liang, J.; Gao, H.; Chou, S.; Pei, Q. Efficient white polymer light-emitting electrochemical cells. Mater. Horiz. 2015, 2, 338-343. [CrossRef]

39. Vak, D.; Oh, S.-H.; Kim, D.-Y. Efficient single-component light-emitting electrochemical cells with an ion-conducting water-soluble polyfluorene. Appl. Phys. Lett. 2009, 94, 243305. [CrossRef]

40. Mandal, S.S.; Varshney, U.; Bhattacharya, S. Role of the central metal ion and ligand charge in the DNA binding and modification by metallosalen complexes. Bioconjugate Chem. 1997, 8, 798-812. [CrossRef]

41. Piotto, S.; Concilio, S.; Sessa, L.; Diana, R.; Torrens, G.; Juan, C.; Caruso, U.; Iannelli, P. Synthesis and Antimicrobial Studies of New Antibacterial Azo-Compounds Active against Staphylococcus aureus and Listeria monocytogenes. Molecules 2017, 22, 1372. [CrossRef]

42. Oliveri, I.P.; Failla, S.; Colombo, A.; Dragonetti, C.; Righetto, S.; Di Bella, S. Synthesis, characterization, optical absorption/fluorescence spectroscopy, and second-order nonlinear optical properties of aggregate molecular architectures of unsymmetrical Schiff-base zinc(II) complexes. Dalton Trans. 2014, 43, 2168-2175. [CrossRef] [PubMed]

43. Diana, R.; Panunzi, B.; Tuzi, A.; Piotto, S.; Concilio, S.; Caruso, U. An amphiphilic pyridinoyl-hydrazone probe for colorimetric and fluorescence $\mathrm{pH}$ sensing. Molecules 2019, submitted.

44. Feng, W.-X.; Yin, S.-Y.; Pan, M.; Wang, H.-P.; Fan, Y.-N.; Lü, X.-Q.; Su, C.-Y. PMMA-copolymerized color tunable and pure white-light emitting $\mathrm{Eu}^{3+}-\mathrm{Tb}^{3+}$ containing Ln-metallopolymers. J. Mater. Chem. C 2017, 5, 1742-1750. [CrossRef] 
45. Argeri, M.; Borbone, F.; Caruso, U.; Causà, M.; Fusco, S.; Panunzi, B.; Roviello, A.; Shikler, R.; Tuzi, A. Color tuning and noteworthy photoluminescence quantum yields in crystalline mono-/dinuclear ZnII complexes. Eur. J. Inorg. Chem. 2014, 2014, 5916-5924. [CrossRef]

46. Borbone, F.; Caruso, U.; Causà, M.; Fusco, S.; Panunzi, B.; Roviello, A.; Shikler, R.; Tuzi, A. Series of $\mathrm{O}, \mathrm{N}, \mathrm{O}$-tridentate ligands zinc(II) complexes with high solid-state photoluminescence quantum yield. Eur. J. Inorg. Chem. 2014, 2014, 2695-2703. [CrossRef]

47. Panunzi, B.; Diana, R.; Concilio, S.; Sessa, L.; Tuzi, A.; Piotto, S.; Caruso, U. Fluorescence pH-dependent sensing of $\mathrm{Zn}(\mathrm{II})$ by a tripodal ligand. A comparative X-ray and DFT study. J. Lumin. 2019, 212, 200-206. [CrossRef]

48. Diana, R.; Panunzi, B.; Tuzi, A.; Caruso, U. Two tridentate pyridinyl-hydrazone zinc(II) complexes as fluorophores for blue emitting layers. J. Mol. Struct. 2019, 1197, 672-680. [CrossRef]

49. Caruso, U.; Panunzi, B.; Roviello, A.; Tingoli, M.; Tuzi, A. Two aminobenzothiazole derivatives for Pd(II) and $\mathrm{Zn}$ (II) coordination: Synthesis, characterization and solid state fluorescence. Inorg. Chem. Commun. 2011, 14, 46-48. [CrossRef]

50. Sun, X.; Wang, Y.; Lei, Y. Fluorescence based explosive detection: from mechanisms to sensory materials. Chem. Soc. Rev. 2015, 44, 8019-8061. [CrossRef]

51. Taraba, L.; Krizek, T.; Kozlik, P.; Hodek, O.; Coufal, P. Protonation of polyaniline-coated silica stationary phase affects the retention behavior of neutral hydrophobic solutes in reversed-phase capillary liquid chromatography. J. Sep. Sci. 2018, 41, 2886-2894. [CrossRef]

52. Hou, S.-S.; Fan, N.-S.; Tseng, Y.-C.; Jan, J.-S. Self-assembly and hydrogelation of coil-sheet poly(1-lysine)-block-poly(1-threonine) Block Copolypeptides. Macromolecules 2018, 51, 8054-8063. [CrossRef]

53. Shu, W.; Guan, C.; Guo, W.; Wang, C.; Shen, Y. Conjugated poly(aryleneethynylenesiloles) and their application in detecting explosives. J. Mater. Chem. 2012, 22, 3075-3081. [CrossRef]

54. Sivalingam, S.; Debsharma, K.; Dasgupta, A.; Sankararaman, S.; Prasad, E. Effect of Slip-Stack Self-Assembly on Aggregation-Induced Emission and Solid-State Luminescence in 1,3-Diarylpropynones. ChemPlusChem 2019, 84, 392-402. [CrossRef]

55. Borbone, F.; Tuzi, A.; Panunzi, B.; Piotto, S.; Concilio, S.; Shikler, R.; Nabha, S.; Centore, R. On-off mechano-responsive switching of ESIPT luminescence in polymorphic n-salicylidene-4-amino-2-methylbenzotriazole. Cryst. Growth Des. 2017, 17, 5517-5523. [CrossRef]

56. Diana, R.; Panunzi, B.; Concilio, S.; Marrafino, F.; Shikler, R.; Caruso, T.; Caruso, U. The Effect of Bulky Substituents on Two $\pi$-Conjugated Mesogenic Fluorophores. Their Organic Polymers and Zinc-Bridged Luminescent Networks. Polymers 2019, 11, 1379. [CrossRef]

57. Panunzi, B.; Diana, R.; Concilio, S.; Sessa, L.; Shikler, R.; Nabha, S.; Tuzi, A.; Caruso, U.; Piotto, S. Solid-state highly efficient $\mathrm{dr}$ mono and poly-dicyano-phenylenevinylene fluorophores. Molecules 2018, 23, 1505. [CrossRef]

58. Caruso, U.; Panunzi, B.; Diana, R.; Concilio, S.; Sessa, L.; Shikler, R.; Nabha, S.; Tuzi, A.; Piotto, S. AIE/ACQ effects in two DR/NIR emitters: A structural and DFT comparative analysis. Molecules 2018, 23, 1947. [CrossRef]

59. Liu, C.-F.; Jiu, Y.; Wang, J.; Yi, J.; Zhang, X.-W.; Lai, W.-Y.; Huang, W. Star-shaped single-polymer systems with simultaneous RGB emission: design, synthesis, saturated shite electroluminescence, and amplified spontaneous emission. Macromolecules 2016, 49, 2549-2558. [CrossRef]

60. Fan, C.; Li, Y.; Yang, C.; Wu, H.; Qin, J.; Cao, Y. Phosphoryl/sulfonyl-substituted iridium complexes as blue phosphorescent emitters for single-layer blue and white organic light-Emitting diodes by solution process. Chem. Mater. 2012, 24, 4581-4587. [CrossRef]

61. Arasu, V.; Jo, D.; Chae, H.; Chung, H.K.; Park, S.H. Configuration- and concentration-dependent hybrid white light generation using red, green, and blue quantum dots embedded in DNA thin films. Nanoscale Adv. 2019, 1, 602-612. [CrossRef]

62. Gautier, R.; Massuyeau, F.; Galnon, G.; Paris, M. Lead halide post-perovskite-type chains for high-efficiency white-light emission. Adv. Mater. 2019, 31, 1807383. [CrossRef] [PubMed]

63. Geng, Y.; Chen, S.; Wang, T.; Yu, D.; Peng, C.; Liu, H.; Hu, Y. Density, viscosity and electrical conductivity of 1-butyl-3-methylimidazolium hexafluorophosphate + monoethanolamine and $+\mathrm{N}, \mathrm{N}$-dimethylethanolamine. J. Mol. Liq. 2008, 143, 100-108. [CrossRef] 
64. Chandran, M.; Kwon, Y.; Choe, Y. Light Emitting Electrochemical Cells Based on Ionic Iridium Complexes and Ionic Conductor Blend as the Active Layer. Mol. Cryst. Liq. Cryst. 2014, 601, 173-181. [CrossRef]

65. Shanmugasundaram, K.; Subeesh, M.S.; Sunesh, C.D.; Chitumalla, R.K.; Jang, J.; Choe, Y. Synthesis and photophysical characterization of an ionic fluorene derivative for blue light-emitting electrochemical cells. Org. Electron. 2015, 24, 297-302. [CrossRef]

66. Di Marcantonio, M.; Namanga, J.E.; Smetana, V.; Gerlitzki, N.; Vollkommer, F.; Mudring, A.V.; Bacher, G.; Nannen, E. Green-yellow emitting hybrid light emitting electrochemical cell. J. Mater. Chem. C 2017, 5, 12062-12068. [CrossRef]

67. Sakanoue, T.; Li, J.; Tanaka, H.; Ito, R.; Ono, S.; Kuroda, S.I.; Takenobu, T. High Current Injection into Dynamic p-n Homojunction in Polymer Light-Emitting Electrochemical Cells. Adv. Mater. 2017, 29, 1606392. [CrossRef]

68. Wang, Y.Z.; Epstein, A.J. Interface Control of Light-Emitting Devices Based on Pyridine-Containing Conjugated Polymers. Acc. Chem. Res. 1999, 32, 217-224. [CrossRef]

69. Maruyama, S.; Prastiawan, I.B.H.; Toyabe, K.; Higuchi, Y.; Koganezawa, T.; Kubo, M.; Matsumoto, Y. Ionic conductivity in ionic liquid nano thin films. ACS Nano 2018, 12, 10509-10517. [CrossRef]

70. Watanabe, M.; Mizumura, T. Conductivity study on ionic liquid/polymer complexes. Solid State Ionics 1996, 86, 353-356. [CrossRef]

(C) 2019 by the authors. Licensee MDPI, Basel, Switzerland. This article is an open access article distributed under the terms and conditions of the Creative Commons Attribution (CC BY) license (http://creativecommons.org/licenses/by/4.0/). 